\title{
Date Palm Tree (Phoenix dactylifera L.): Natural Products and Therapeutic Options
}

\author{
Reem A. Al-Alawi, Jawhara H. Al-Mashiqri, Jawaher S. M. Al-Nadabi, Badria I. Al-Shihi and \\ Younis Baqi *
}

Department of Chemistry, Faculty of Science, Sultan Qaboos University, Muscat, Oman

Many plants, including some of the commonly consumed herbs and spices in our daily food, can be safely and effectively used to prevent and/or treat some health concerns. For example, caffeine the active ingredient found in coffee beans (Coffea), shows biological activity in the treatment of the central nervous system (CNS) disorders, indole-3-carbinol, and 3,3'-diindolylmethane are both broccoli (Brassica oleracea) derived phytochemicals with potential anti-cancer activity, and resveratrol, isolated from grape (Vitis vinifera), is reported to extend lifespan and provide cardio-neuro-protective, anti-diabetic, and anti-cancer effects. Date palm fruits possess high nutritional and therapeutic value with significant antioxidant, antibacterial, antifungal, and anti-proliferative properties.

OPEN ACCESS

Edited by:

Hiroyuki Morita,

University of Toyama, Japan

Reviewed by:

Katsuhiro Konno,

University of Toyama, Japan

Maurice D. Awouafack,

University of Dschang, Cameroon

${ }^{*}$ Correspondence:

Younis Baqi

baqi@squ.edu.om

Specialty section:

This article was submitted to Plant Metabolism and Chemodiversity,

a section of the journal

Frontiers in Plant Science

Received: 18 February 2017

Accepted: 05 May 2017

Published: 23 May 2017

Citation:

Al-Alawi RA, Al-Mashiqri JH, Al-Nadabi JSM, Al-Shihi Bl and Baqi Y

(2017) Date Palm Tree (Phoenix dactylifera L.): Natural Products and

Therapeutic Options.

Front. Plant Sci. 8:845.

doi: $10.3389 /$ fp/s.2017.00845
This review focuses on the date fruit extracts and their benefits in individual health promoting conditions and highlights their applications as useful to the pharmaceutical and nutraceutical industries in the development of natural compound-based industrial products.

Keywords: antioxidant, Arecaceae, cancer, date fruit, palm tree, Phoenix dactylifera L.

\section{INTRODUCTION}

Date palm tree (Phoenix dactylifera L.) is considered as one of the oldest and main staple and ancient crops in Southwest Asia and North Africa. Besides, dates can be grown in Australia, Mexico, South America, southern Africa, and the United States, especially in southern California, Arizona, and Texas (Chao and Krueger, 2007; Al-Harrasi et al., 2014; Hazzouri et al., 2015). Date palm tree belongs to Arecaceae family (Angiosperms, monocotyledon) consisting of about 200 genera and more than 2,500 species. Phoenix (Coryphoideae phoeniceae) is one of the genera with approximately 14 species (Table $\mathbf{1}$ ), which are native to the tropical or subtropical regions of southern Asia or Africa, including Phoenix dactylifera L (Siddiq et al., 2013; Eoin, 2016). The name of the species dactylifera means "finger-bearing" which refers to the fruit clusters produced by this plant. Dactylifera is a grouping of the Greek word dactylus, means "finger," and the Latin word ferous, mean "bearing" (Ashraf and Hamidi-Esfahani, 2011). Very recently the whole genome of date palm tree was re-sequenced yields insights into diversification of a fruit tree crop (Hazzouri et al., 2015).

Flowers of date palm tree are small and yellow colored attached directly to spikelets which develop as fruits called date palm fruits (El Modafar and El Boustani, 2001; Biglari et al., 2007). The world geographical distribution of the genus "phoenix" is described in Table 1. Economically and due to the fast growing demand, the production of the dates has been increased over the years. Taking in consideration the top 20 date producing countries, the production of dates was 
TABLE 1 | Species of the genus Phoenix along with their common local name and geographical distribution.

\begin{tabular}{|c|c|c|}
\hline Species & Local name & Geographical distribution \\
\hline Phoenix acaulis & Stemless date palm & Bhutan, Nepal, Northern India \\
\hline Phoenix andamanensis & $\begin{array}{l}\text { Andaman Island date } \\
\text { palm }\end{array}$ & Myanmar \\
\hline Phoenix atlantica & Cape Verde Island & Cape Verde Islands \\
\hline Phoenix caespitosa & Date palm & $\begin{array}{l}\text { Djibouti, Oman, Saudi Arabia, } \\
\text { Somalia, Yemen }\end{array}$ \\
\hline Phoenix canariensis & $\begin{array}{l}\text { Canary Island date } \\
\text { palm }\end{array}$ & $\begin{array}{l}\text { Australia, Bermuda, Canary } \\
\text { Islands, Italy, Spain }\end{array}$ \\
\hline Phoenix dactylifera L. & Date palm & $\begin{array}{l}\text { Arabian Peninsula, Australia, } \\
\text { California, China, El Salvador, Fiji, } \\
\text { Iran, India, Mauritius, northern } \\
\text { and western Africa, Pakistan, } \\
\text { Spain }\end{array}$ \\
\hline Phoenix loureiroi & Mountain date palm & $\begin{array}{l}\text { China, Himalayas, India, } \\
\text { Indochina, Philippines }\end{array}$ \\
\hline Phoenix paludosa & Mangrove date palm & $\begin{array}{l}\text { Andaman, India, Indochina, } \\
\text { Sumatra }\end{array}$ \\
\hline Phoenix pusilla & Ceylon date palm & India, Sri Lanka \\
\hline Phoenix reclinata & Senegal date palm & $\begin{array}{l}\text { Africa, Arabian Peninsula, } \\
\text { Comoros, Madagascar }\end{array}$ \\
\hline Phoenix roebelenii & Pygmy date palm & $\begin{array}{l}\text { China (Yunnan) to North } \\
\text { Indo-China }\end{array}$ \\
\hline Phoenix rupicola & Cliff date palm & Andaman Islands, Bhutan, India \\
\hline Phoenix sylvestris & Indian date palm & $\begin{array}{l}\text { Indian Subcontinent, Myanma, } \\
\text { southern China }\end{array}$ \\
\hline Phoenix theophrasti & Cretan date palm & Greek Islands, Turkey \\
\hline
\end{tabular}

about 3.5 million metric tons in 1990, and 10 years later (in 2000) the world production of the top 20 countries increased to reach almost the double (ca. 6.5 million metric tons), while the latest statistical calculation available, for 2014, is exceeding the seven million and half metric tons (Figure 1) (FAO, http://www.fao.org).

Date palm fruits are berry containing a single seed enclosed by fibrous parchment like endocarp, fleshy mesocarp and the fruit skin (pericarp). Different region give different dates which vary in shape, size, and weight. Also, they can vary in their organoleptic, physical and chemical characteristics (Al-Qarawi et al., 2004; Barghini et al., 2007). It is oblong in shape though certain verities might reach near spherical shape. Date palm tree starts fruiting at an average age of 5 years with an average production of 400-600 $\mathrm{kg} / \mathrm{tree} /$ year and continues to produce for up to 60 years. Egypt, Iran, Algeria, Saudi Arabia, Iraq, Pakistan, Sudan, Oman, UAE, and Tunisia are the top ten date producing countries (Figure 2). Over 100 million date palm trees scatter on ca. 1.3 million hectare worldwide (FAO, http://www.fao.org). The biggest contributed area is the Asian continent including Middle Eastern countries (833,351 hectare), followed by Africa with 416,695 out of which 392, 200 hectare in North Africa alone (Al-Shahib and Marshall, 2013).

The five stages of pre-maturation, maturation and ripening of date are Hababauk, Kimri, Khalal, Rutab, and Tamer (Figure 3; Al-Mssallem et al., 2013). Depending on the maturity and ripeness stages during growth and development of the date, different external and internal changes are observed with color, sweetness, texture and chemical composition (Al-Mssallem et al., 2013; Al-Shahib and Marshall, 2013). Date contains many nutrients such as: carbohydrates, proteins, fat, minerals and vitamins (Al-Qarawi et al., 2004; Barghini et al., 2007).

The most important quality attributes to grade dates are color, flavor (sugar level), moisture (26-30\%) and absence of defects such as insect, damage, cracks and surface damage. Date fruit is good source of high nutritional value food. Indeed it is rich in carbohydrates, dietary fibers, proteins, minerals and vitamin $B$ complex, such as thiamine $\left(B_{1}\right)$, riboflavin $\left(B_{2}\right)$, niacin $\left(B_{3}\right)$, pantothenic $\left(B_{5}\right)$, pyridoxine $\left(B_{6}\right)$, and folate $\left(B_{9}\right)$ (Chao and Krueger, 2007; Al-Harrasi et al., 2014; Siddiq et al., 2013; Eoin, 2016). In more details, carbohydrates forms $70 \%$ of date fruit and are mostly fructose and glucose in equal ratio while date proteins are rich in amino acids that contain acidic side chain but poor in methionine and cysteine, which their side chain composed of sulfur. Minerals in date fruits are calcium, iron, magnesium, selenium, copper, phosphorus, potassium, zinc, sulfur, cobalt, fluorine, manganese, and boron (Chao and Krueger, 2007; Al-Harrasi et al., 2014; Siddiq et al., 2013; Eoin, 2016). The edible part of the date palm tree has been recognized to possess many medicinal properties when consumed alone or in mixture with other medicinal herbs (Tiwari et al., 2013). In recent years, a huge interest in the abundant health promoting properties of date fruits had led to many pharmacological studies (in-vitro and in-vivo) as well as the identification and quantification of different classes of phytochemicals (Chao and Krueger, 2007). The date fruits are highly nourishing and may have numerous potential health benefits. The protective effects of fruits against chronic diseases are ascribed to bioactive non-nutrients called phytochemicals. Phytochemicals have gained increased interest among several investigators, including clinicians due to their antioxidant activity, cholesterol-lowering properties, and other potential health benefits such as chemoprevention of cancer, prevention of diabetes and cardiovascular diseases (Chao and Krueger, 2007; Tiwari et al., 2013; Al-Harrasi et al., 2014).

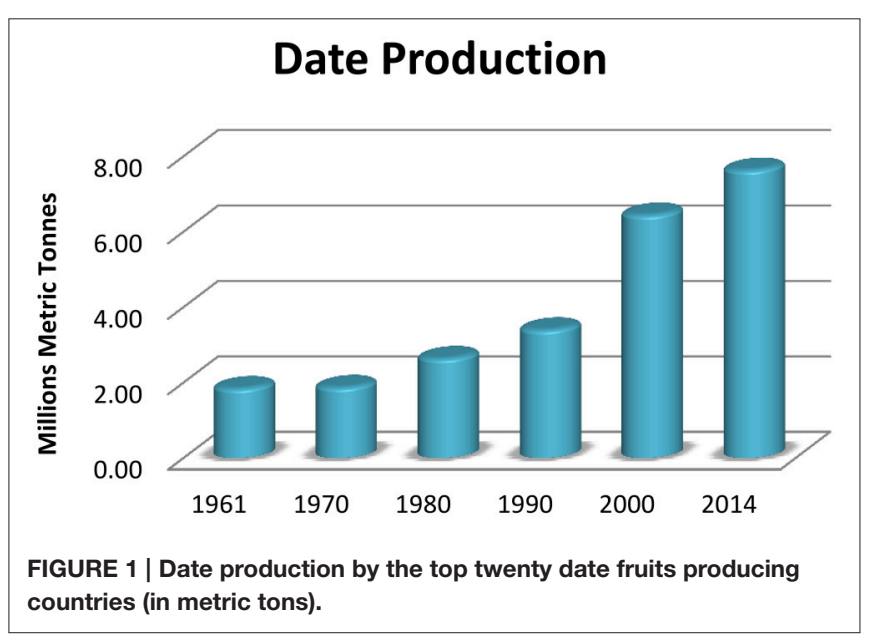




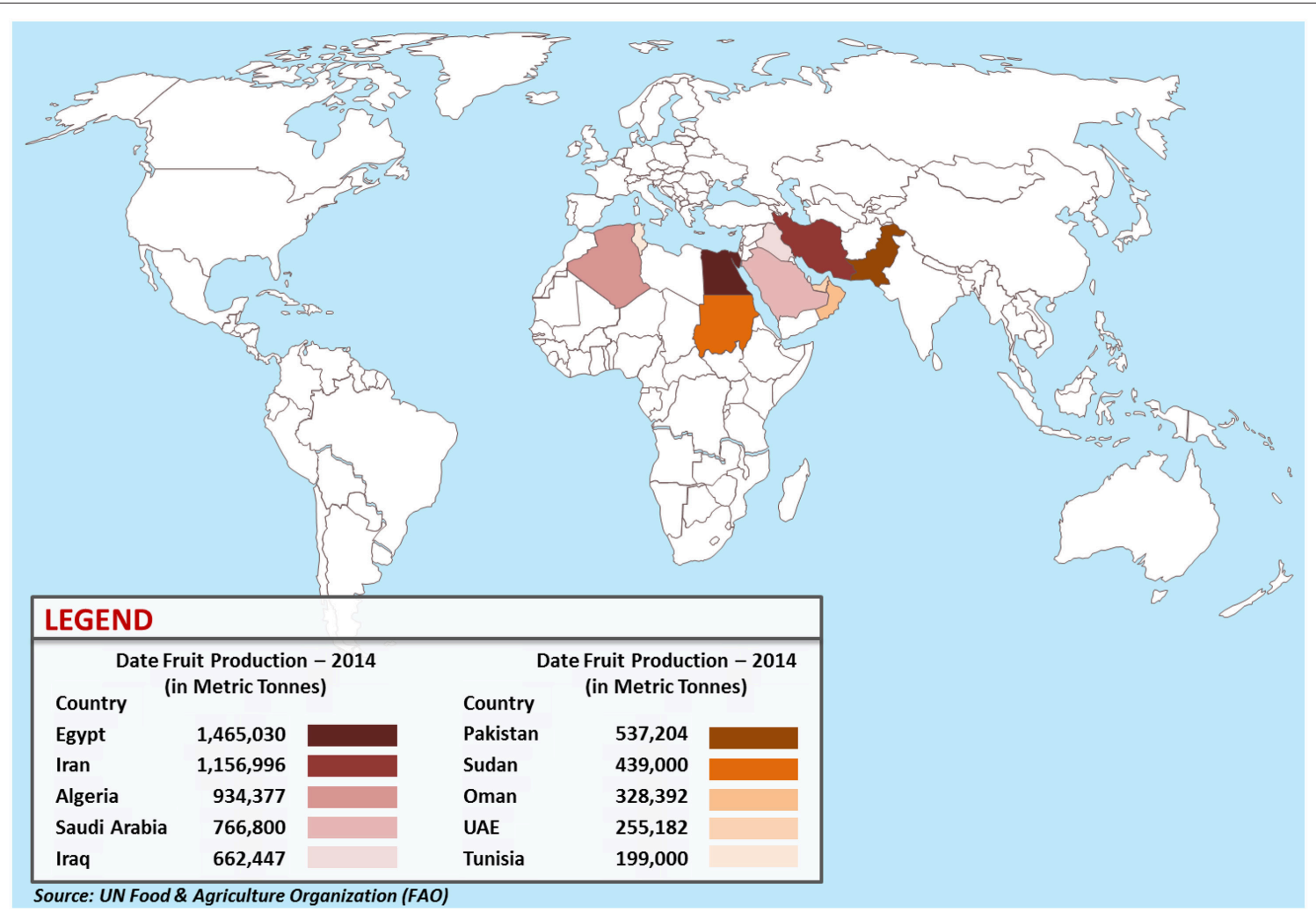

FIGURE 2 | World map of the top ten date fruit producing countries in 2014.

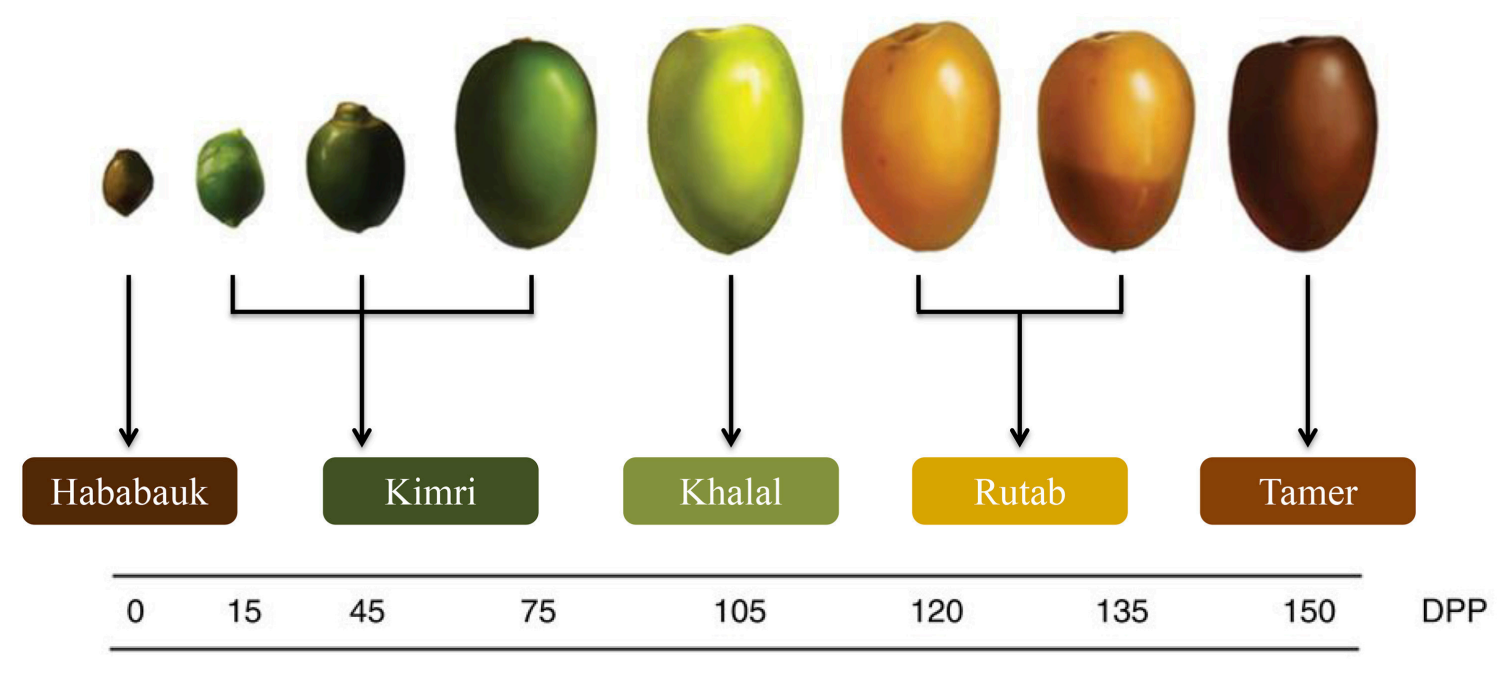

FIGURE 3 | The five growth stages of a date fruit by days post pollination (DPP) (Al-Mssallem et al., 2013).

\section{PHYTOCHEMICALS IN DATE PALM FRUITS}

Phytochemicals are plant-derived chemicals which may give health benefits when taken as a medicine drug or as a part of daily diet. They are classified into two main categories: primary metabolites, which occur in all cells and play an essential role in the reproduction and metabolism of those cells, for example nucleic acids, the common amino acids and carbohydrates (sugars); secondary metabolites such as terpenes (a group of lipids), phenolics (derived from carbohydrates), alkaloids (derived from amino acids) which are characteristic of a limited range of species and have a biological effect on other 
organism (Thatoi and Patra, 2011; Dias et al., 2012). Many of biologically active constituents of medicinal, commercial and poisonous plants are classified as secondary metabolites. Date fruit is rich in phytochemicals such as carotenoids, polyphenols (e.g., phenolic acids, isoflavons, lignans, and flavonoids), tannins, and sterols (Martín-Sánchez et al., 2014). The concentration and composition of these constituents are widely varied depending on several parameters, including date variety, stage of fruit picking, storage, postharvest processing, the geographical origin of the dates and soil conditions (Al-Laith, 2009; Amorós et al., 2009; Al-Turki et al., 2010). Several researchers have reported that the chemical constituents and functional composition of date fruits are dramatically changed during date maturing period with increasing in levels of reducing sugars, while fiber, mineral, and vitamin levels decreasing steadily (Kikuchi and Miki, 1978; Al-Farsi et al., 2007; Al-Turki et al., 2010).

\section{Carotenoids}

Carotenoids considered as a major class of phytochemicals occur in the lipid fractions of date fruit. They are precursors of vitamin A, which plays a central role in vision, and protects the cell from deleterious effects of free radicals by acting as antioxidants (Julia et al., 2015). Carotenoid classification is depending on the presence or absence of oxygen in the molecule, they can be divided into two main subclasses: xanthophylls (contain oxygen atom) and carotenes (lack oxygen atom). Boudries et al. studied the carotenoid composition for three different varieties at three edible maturation stages (Khalal, Rutab, and Tamr) and they found that dates contain lutein and $\beta$-carotene as major carotenoids (Boudries et al., 2007). Neoxanthin, violaxanthin, and antheraxanthin were identified in date fruits in lesser amount (Figure 4). Al Farsi et al. analyzed the total carotenoids for three date fruit varieties (Fard, Khasab, and Khalas) and they found that Khalas has the highest amount of carotenoids as expected as this variety has a yellow color. They also reported destruction of total carotenoids after sun drying of date fruit ranged between 4 and $30 \%$ (Al-Farsi et al., 2005a). Dried date fruit is a moderate source of carotenoid $(0.97 \mathrm{mg} / 100 \mathrm{~g})$ compared to other dried fruits, e.g., figs and apricot: $0.032 \mathrm{mg} / 100 \mathrm{~g}$ and: $2.20 \mathrm{mg} / 100 \mathrm{~g}$ respectively (Martín-Sánchez et al., 2014).

\section{Phytosterols and Phytoestrogens}

Phytosterols are another major phytochemicals that found in the lipid soluble fraction of the date fruit. These compounds are exclusively occurring in plants with chemical structure similar to that of cholesterol (Al-Laith, 2009). Approximately 200 phytosterols exist in nature and many of them are found in vegetables and fruits (Amorós et al., 2009). Date fruit at tamer stage contains several phytosterols. Back in 1978, cystalline plant sterol mixture was first isolated from the edible part of date fruit and has been identified to include $\beta$-sitosterol, stigmasterol, campesterol, and isofucosterol (Figure 5; Kikuchi and Miki, 1978). However, the difference in the phytosterol composition among the date fruit varieties and its ripening stages is still unclear and therefore make it an important line for advance research. Moreover phytoestrogens are natural compounds that can bind estrogen receptors and exert diverse estrogenic or antiestrogenic effects (Al-Turki et al., 2010). Thompson et al. studied the phytoestrogens content in date fruit and they identified several phytoestrogens including formononetin, daidzein, genistein, glycitein, matairesinol, lariciresinol, pinoresinol, secoisolariciresinol, and coumestrol (Figure 5; Thompson et al., 2006).

\section{Phenolic Acids}

Phenolic acids considered as one of the main aromatic secondary plant metabolites, containing hydroxyl function located on aromatic benzene ring with one or more carboxylic acid groups. Phenolic acids can be divided into two main classes: benzoic acid derivatives of which contain seven carbon atoms and cinnamic acid derivatives of which contain nine carbon atoms. They considered as effective antioxidant because they act as free radical captor or scavenger. Several research groups reported that dates are rich in phenolic acids (Saleh et al., 2011; Benmeddour et al., 2013; El Sohaimy et al., 2015). Al Farsi et al. studied three different Omani date fruits (Fard, Khasab, and Khalas) and found to contain the following benzoic acid derivatives; p-hydroxybenzoic acid, protocatechuic acid, vanillic acid, gallic acid and syringic acid, while the cinnamic acid derivatives were; $o$-coumaric acid, $p$-coumaric acid, caffeic acid, and ferulic acid (Figure 6; Al-Farsi et al., 2005a). In another study of seven different varieties of date fruits cultivated in Algeria, Mansouri et al. identified the main phenolic acids including $p$-coumaric acid, ferulic acid and sinapic acid. Moreover, three different isomers of 5-o-caffeoyl shikimic acid were identified, in addition xanthoxylin acid, hydrocaffeic acid, and coumaroylquinic acid were reported (Figure 6; Mansouri et al., 2005). Karasawa et al. identified protocatechuic acid, syringic acid, caffeic acid, ferulic acid, and chlorogenic acid in the date extract using UPLC by comparing the retention time and UV spectrum of the peaks of these compounds with those of standard phenolic acids (Figure 6; Karasawa et al., 2011). The major phenolic acids in Saudi date fruit varieties were gallic acid, $p$-coumaric acid, and ferulic acid derivatives (Hamad et al., 2015). Recently, Borochov-Neori et al. studied the phenolic composition of two date varieties, Amari and Hallawi, at Tamr stage. The phenolic fractions have been analyzed by RP-HPLC using system software based on UV/Vis absorbance spectra and the retention times of the chromatogram peaks were compared with library of authentic related standard compounds. The quantity of each individual phenolic compounds were calculated from the corresponding area under the curve of the chromatogram peak with the help of the software in triplicate runs, and compared with authentic standards of caffeic acid, coumaric acid, ferulic acid, and salicylic acid and kaempferol-3-glucoside. They detected five and seven phenolic acids constituent in Hallawi and Amari, respectively. The major component of the phenolic fraction was ferulic acid and a trace amount of coumaric acid for both varieties. Amari found to contain mostly caffeic acid derivatives, while salicylic acid was the most abundant phenolic acid in Hallawi (BorochovNeori et al., 2015). Protocatechuic acid, vanillic acid, gallic acid, syringic acid and $p$-coumaric acid were detected in three different Tunisian date fruit varieties (Figure 6; Mrabet et al., 2016). Lemine et al. found that the amount of phenolic acids 
<smiles>CC1=C[C@@H](O)CC(C)(C)C1/C=C/C(C)=C/C=C/C(C)=C/C=C/C=C(C)/C=C/C=C(C)/C=C/C1=C(C)C[C@@H](O)CC1(C)C</smiles>

FIGURE 4 | Chemical structures of carotenoids identified in date fruits.

in Khalal stage of date is significantly higher than in the fully mature Tamer stage, $0.729 \mathrm{~g} / 100 \mathrm{~g}$, and $0.559 \mathrm{~g} / 100 \mathrm{~g}$ (wt/wt), respectively (Lemine et al., 2014).

Moreover, Awad et al. reported that the quantity of phenolic compounds decreased, with a $25 \%$ loss through the ripening stages from the Khalal to the Tamar in date fruits cultivar from Tunisia (Awad et al., 2011). However, Al-Najada and Mohamed studied the change of total phenolic contents of Khalas and Shishi date fruits during storage at $4^{\circ} \mathrm{C}$ and they reported that the phenolic contents significantly increased after 6 months, while after 12 months of storage the phenolic contents increase up to ca. double the amount (Al-Najada and Mohamed, 2014).

\section{Flavonoids}

Flavonoids are large family of polyphenolic plant derived secondary metabolites, comprise of 15 carbons skeleton containing two aromatic benzene rings $\mathrm{A}$ and $\mathrm{C}$ chemically bound via a heterocyclic pyrane ring $\mathrm{C}$ and this skeleton is often substituted with multiple substitution patterns (Figure 7). Flavonoids are classified into several subgroups, including flavones, flavonols, flavanones, flavanonol, isoflavones, isoflavonone, flavan-3-ols, and anthocyanidins. Flavonoids are found in a variety of fruits and vegetables with notable health benefits as antioxidant and anti-inflammatory (Moss and Ramji, 2016). Hong et al. studied the flavonoid glycoside and procyanidin compositions of date fruit, variety Deglet Noor, harvested at Khalal stage of maturity by liquid chromatography-electrospray ionization/tandem mass spectrometry (LCESI/MS/MS) and found that it contain 13 flavonoid glycosides of apigenin, luteolin, and quercetin, 19 in isomeric forms (Figure 7), in addition they reported flavonoid sulfates (Hong et al., 2006). Chaira et al. reported that Korkobbi variety has the highest level of flavonoids among 10 Tunisian date varieties, as a consequence, it shows the highest antiradical efficiency of this cultivar (Chaira et al., 2009). In Oman, the total flavonoid content has been investigated for three major date varieties; Fardh, Khasab, and Khalas at two edible maturation stages; Rutab and Tamr (Singh et al., 2012). Michael et al. found a new diosmetin glycosides; diosmetin 7-O- $\beta$-L-arabinofuranosy $(1 \rightarrow 2)-\beta$-D-apiofuranoside (Diosmetin 1 ) and diosmetin 7-O$\beta$-D-apiofuranoside (Diosmetin 2), which was isolated from acetone extract of date fruits (Figure 7; Michael et al., 2013).

In another study on 11 different Saudi date fruit varieties, apigenin, luteolin, quercetin, isoquercetrin, and rutin were identified (Hamad et al., 2015). Kaempferol, a natural flavonol, derivatives were identified in Amari and Hallawi date fruits, where Amari contained five flavonol in a significant amount and Hallawi contained one major flavonol (Borochov-Neori et al., 2015). Lemine et al. reported that the total content of flavonoid decrease significantly from Khalal stage to Tamer stage for the seven different date fruits varieties that they examined (Lemine et al., 2014). Another study showed that the flavonoid content reduced during maturity stages from Khalal to Tamer stage for four different studied Tunisian date fruit varieties (Amira et al., 2012). Al Farsi et al. measured the content of anthocyanins in fresh and dried date fruits and these were identified only in fresh dates (Al-Farsi et al., 2005a), this might be due to the destruction after expose it to the sun. It was reported that enzymatic and non-enzymatic browning reactions can cause the destruction of anthocyanins during drying and storage period (Wrolstad, 2004). 


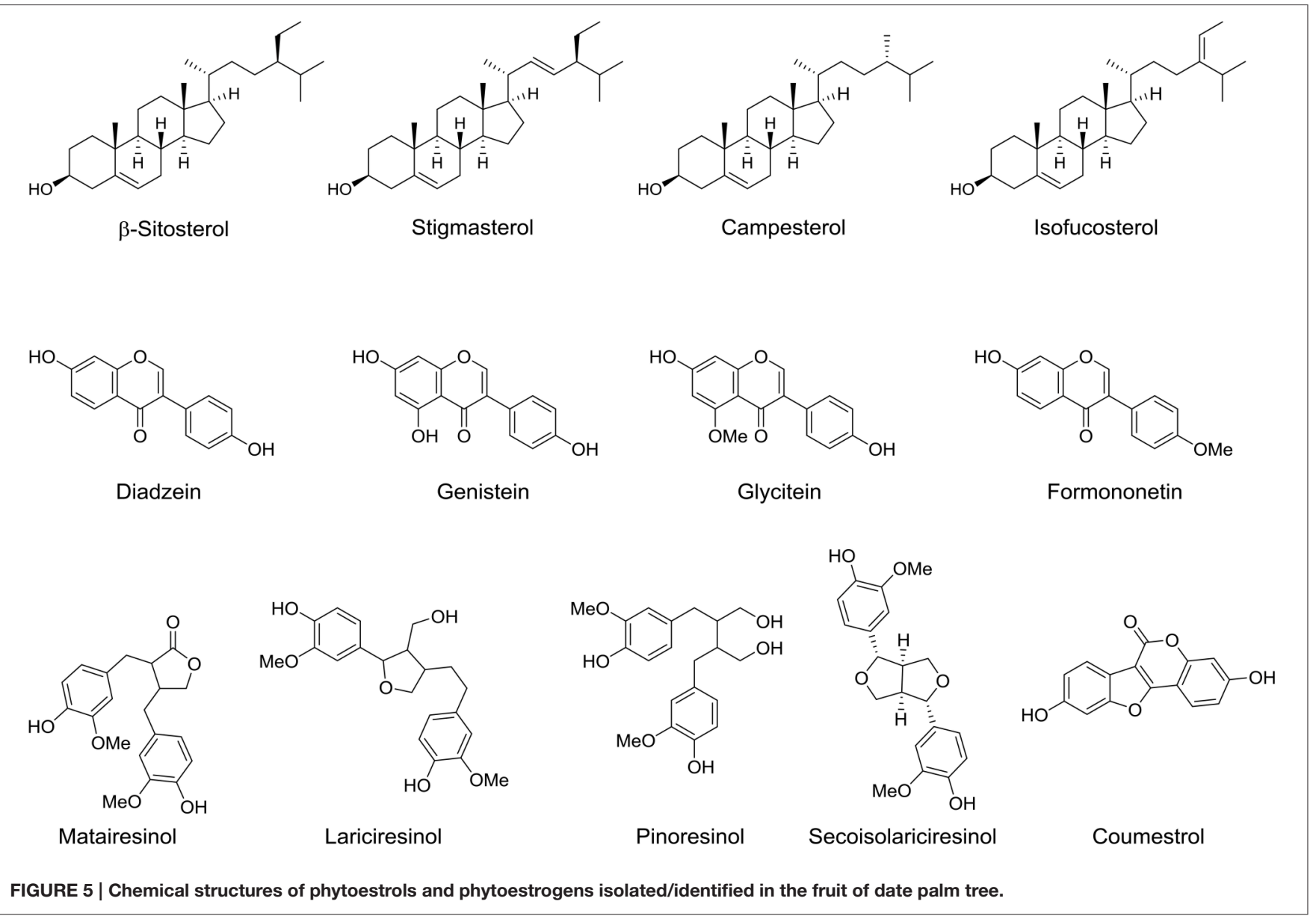

While pelargonin, an anthocyanin was identified in date fruits (Figure 6; Karasawa et al., 2011). Moreover, the total flavanol, including catechin in the edible part found to be more than that in the date pits (Hammouda et al., 2013).

\section{NATURAL PRODUCTS}

Natural products are organic derived compounds produces in-vivo by primary or secondary metabolism, which usually carried out by biocatalytic pathway involving a biocatalyst (enzyme). Since natural products are naturally biosynthesized, these found to interact with very crucial biopolymer molecules in the living cells, such as proteins (enzymes, receptors), DNA and RNA, which these are the same targets for drugs (Mrabet et al., 2016). For example, caffeine the active ingredient found in coffee beans (Coffea), shows biological activity in the treatment of the central nervous system (CNS) disorders (Silva et al., 2013; Kaster et al., 2015), indole-3-carbinol and 3,3'diindolylmethane are both broccoli (Brassica oleracea) derived phytochemicals with potential anti-cancer activity (Wang et al., 2012; Mayne et al., 2016), and resveratrol, isolated from grape (Vitis vinifera), is reported to extend lifespan and provide anti-diabetic, cardio-neuro-protective, and anti-cancer effects (Figure 8) (Sajish and Schimme, 2015; Dance, 2016).
It has been estimated, that $62 \%$ of all modern drugs are of natural products origin, of which (14\%) are mimic of natural product or containing natural product pharmacophore. The rest $38 \%$ of current drugs are either purely synthesized (27\%) or synthesized to mimic a natural product $(11 \%)$ (Newman and Cragg, 2016). Thereby documenting that natural product compounds have been a successful drug source for the pharmaceutical industry. Moreover, world-health organization reported that ca. $80 \%$ of the world's populations depend on conventional medicine for their primary health care (Awad et al., 2011). Natural products extracted from the fruits of date palm tree has been shown to possess many health promoting properties such as anti-inflammatory, anti-fungal, anti-oxidant and antitumor effects (Al-Qarawi et al., 2004; Vayalil, 2012; Rahmani et al., 2014).

\section{THERAPEUTIC OPTIONS}

Antioxidants have received great attention because they act as free radicals scavenger related to various diseases including cancer (Gorrini et al., 2013), heart diseases (Moss and Ramji, 2016), Alzheimer's (Frost et al., 2014), and Parkinson's disease (Kim et al., 2015). Oxidative stress happens when the production of reactive oxygen species (ROS) is 


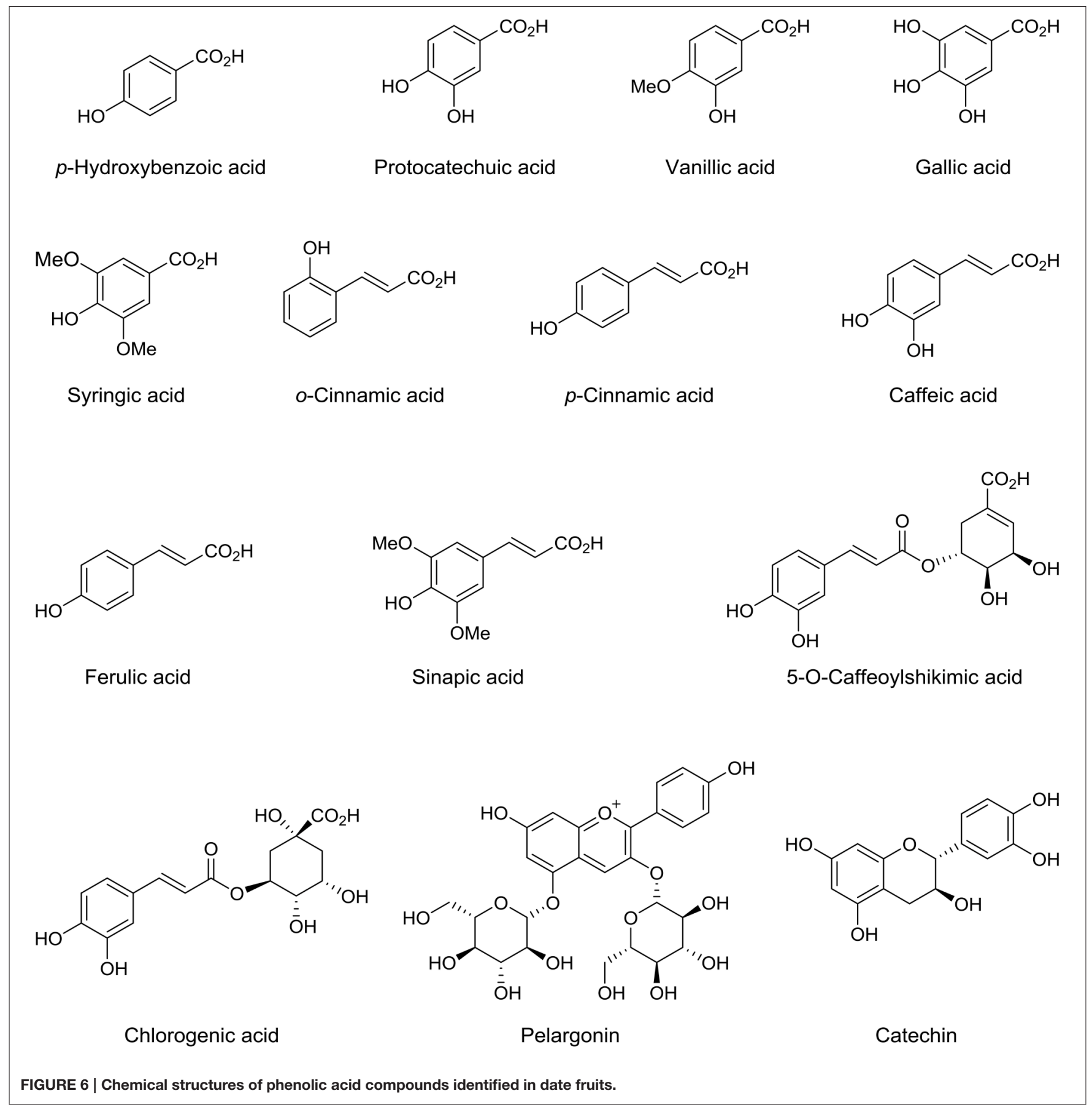

greater than the ability of the body to detoxify the reactive intermediates. The body naturally produces antioxidants such as, superoxide dismutase (SOD), catalase, glutathione peroxidase (GSHPx) to protect itself against free radicals. The antioxidants neutralize the free radicals, so rendering them harmless to other cells (Nathan and CunninghamBussel, 2013). However these endogenous antioxidants are not enough to neutralize all of the free radicals generated in the body.
A daily diet intake rich in vegetables and fruits has been shown to reduce oxidative damage of DNA bases in humans (Kotepui, 2016), protective for heart disease (Harasym and Oledzki, 2014) and protect against lipid peroxidation (Basu et al., 2014). The antioxidant activity of phenolic compounds is found to be comparable to the standard antioxidants, such as vitamin $\mathrm{C}$, vitamin $\mathrm{E}$, and $\beta$-carotene (Rautiainen et al., 2016). Earlier investigation reported that date fruits have the highest concentration of total polyphenols among the dried 


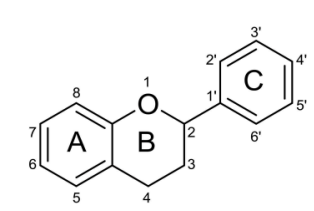

Flavonoid<smiles>O=c1cc(-c2ccc(O)cc2)oc2cc(O)cc(O)c12</smiles>

Apigenin<smiles>O=c1cc(-c2ccc(O)c(O)c2)oc2cc(O)cc(O)c12</smiles>

Luteolin<smiles>O=c1c(O)c(-c2ccc(O)c(O)c2)oc2cc(O)cc(O)c12</smiles>

Quercetin<smiles>COc1ccc(-c2cc(=O)c3c(O)cc(OC4OC(CO)C(O)C(OC(C)O)C4OCCO)cc3o2)cc1O</smiles>

$\mathrm{OH}$

Diosmetin 1<smiles>COc1ccc(-c2cc(=O)c3c(O)cc(OC4OC(CO)CC(O)C4O)cc3o2)cc1O</smiles>

Diosmetin 2<smiles>O=c1c(O)c(-c2ccc(O)cc2)oc2cc(O)cc(O)c12</smiles>

\section{Kaempferol}<smiles>Oc1cc(O)c2c(c1)O[C@H](c1ccc(O)c(O)c1)[C@H](O)[C@H]2c1c(O)cc(O)c2c1O[C@H](c1ccc(O)c(O)c1)[C@H](O)C2</smiles>

Procyanidin $\beta(4 \rightarrow 8)$ Dimers

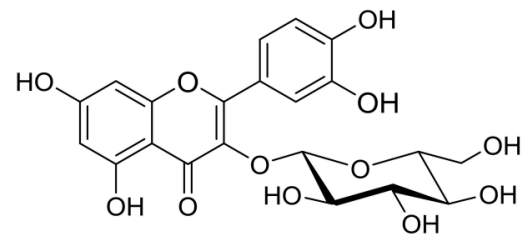

Isoquercetin

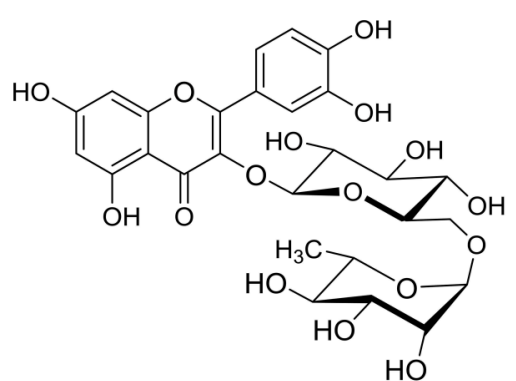

Rutin

FIGURE 7 | Basic flavonoid skeleton and some flavonoids identified in date fruits.<smiles>Cn1c(=O)c2c(ncn2C)n(C)c1=O</smiles>

Caffeine<smiles>OCc1c[nH]c2ccccc12</smiles>

Indole-3-carbinol<smiles>c1ccc2c(Cc3c[nH]c4ccccc34)c[nH]c2c1</smiles>

3,3'-Diindolylmethane<smiles>Oc1ccc(/C=C/c2cc(O)cc(O)c2)cc1</smiles>

Resveratrol

FIGURE 8 | Selected plant derived natural products with paramount health promoting activity.

fruits due to the greater exposure to sunlight and extreme temperature for date fruits compared to other fruits (Vinson et al., 2005). However, their composition can be vary from cultivar to cultivar depending on soil conditions and agronomic practice, for example, the nutritional quality of date fruits alters among varieties grown in Algeria (Saleh et al., 2011) and Oman (Al-Farsi et al., 2005b; Chaira et al., 2009), Bahrain (Allaith, 2008), and Sudan (Mohamed et al., 2014). Guo et al. studied the antioxidant activities of 28 fruits commonly consumed in China and they found that date fruits possess the second highest antioxidant activity after Hawthorn (Guo et al., 2003). In another study, Saafi et al. investigated the effect of aqueous date fruit extract (Deglet Noor variety) on the protection against oxidative damage as well as hepatotoxicity induced by subchronic exposure to dimethoate on rat liver and the data showed that the extract repaired the damage of the liver (Saafi et al., 2011). In different study, Mansouri et al. examined the immunomodulatory effects of a hot water extract from date at tamer stage, prune and fig fruit in mice (Mansouri et al., 2005). They found that date fruit extract promote the cellular system more than prune and fig 
extract. Moreover, it has been reported that diosmetin glycosides (diosmetin 1 and 2, Figure 5) can increase the insulin excretion and stimulate the enzyme glycogen synthase, which maintain homeostasis of blood glucose levels in-vivo using alloxan diabetic male rats (Singh et al., 2012). In addition, the treatment of alloxan diabetic male rats by these two compounds showed a highly increase in serum testosterone level accompanied with a significant decrease in total and prostatic acid phosphate activities (Singh et al., 2012). El Sohaimy et al. measure the antimicrobial activity of some Egyptian date fruit against five pathogenic bacterial strains and they found that the water and ethanol extracts has a strong antibacterial activity (El Sohaimy et al., 2015). Al-Yahya et al. studied the cardioprotective effect of lyophilized aqueous date fruit extract (Ajwa variety) ex-vivo and in-vivo and they found that it enhance the cardiomyoblast cell proliferation by up to $40 \%$, prevented the consumption of endogenous antioxidants and inhibited lipid peroxidation (Al-Yahya et al., 2015). Garba and Galadima investigated the antimicrobial potential of date fruit extract on the bacteria, salmonella spp. and shigella spp., which cause diarrhea. The extracts from water, methanol and petroleum ether showed a significant activity as anti-diarrhea (Garba and Galadima, 2012). Borochov-Neori et al. investigated the antioxidant and antiatherogenic properties of date fruit (Amari and Hallawi varieties) at Tamr stage extract, prepared by acetone/water (7:3, v/v) solution containing $0.5 \%$ acetic acid. Several methods have been used to measure the antioxidant activities of these varieties and were reported to possess antioxidant activity comparable to vitamin C (Borochov-Neori et al., 2015). Moreover, they studied the effect of the isolated phenolic acid and flavonol fractions from date fruits in the extent of cholesterol efflux and they found that the flavonol fractions enhanced cholesterol removal from macrophages. This positive antioxidant effect might protect the cell membrane from being oxidized by the effect free radicals generated both extra- and intracellularly (Borochov-Neori et al., 2015). Lemine et al. studied the anti-oxidant activity of seven different Mauritanian date fruits varieties at two edible stages (Khalal and Tamr) and they found that Khalal has higher antioxidant compare to Tamr stage (Lemine et al., 2014). While $\mathrm{Al}$ Farsi et al. reported the antioxidant activity of three date fruit varieties grown in Oman, namely; Fard, Khasab, and Khalas. The results show that Khalas to possess higher antioxidant activity (Al-Farsi et al., 2005a).

Date fruit may have a potential health benefits against many types of cancer as it suggested by experimental evidence and the phytochemical composition. Al-Sayyed et al. reported the potential cancer preventive effects of date fruit. They found that increase consumption of dried date fruit reduced significantly the incidence rate of mammary cancer, palpable tumor multiplicity, tumor size and weight compared to the positive control group (Al-Sayyed et al., 2014). Eid et al. studied the whole date fruit extract and its polyphenol-rich extract, both extracts were prepared from methanol/water $(4: 1, \mathrm{v} / \mathrm{v})$ containing $10 \%$ of 1 molar sodium fluoride $(\mathrm{NaF})$ solution, found to inhibit Caco-2 cell growth, indicating that both were capable of probably acting as anti-proliferative agents in-vitro. According to their results, consumption of date fruits may promote health condition of the colon by increasing the growth of beneficial bacterial and inhibiting the proliferation of colon cancer cells (Eid et al., 2014). In another study, Zangiabadi et al. studied the effect of aqueous date extract on diabetic polyneuropathy in streptozotocin induced diabetic rats and they reported that date extract was able to prevent the diabetic aggravation and in enhancing pathological parameters of diabetic neuropathy (Zangiabadi et al., 2011). Pujari et al. reported that date extract, prepared using methanol/water (4:1, v/v), gives significant neuroprotection against cerebral ischemia induced by bilateral common carotid artery occlusion (Pujari et al., 2011). Souli et al. suggested that aqueous date fruit extract accelerate the gastrointestinal transit activity and reduces the risk of constipation (Souli et al., 2014). In a very recent study, Belmir et al. investigated the antifungal activity of aqueous date fruit (Ajwa variety) extract at Tamr stage with the amphotericin $B$, an antifungal drug. They reported that therapeutic index of amphotericin B increased significantly with the extract and the cytotoxicity induced by amphotericin B test showed that the aqueous date extract prevents cytotoxicity of red blood cells (Belmir et al., 2016). Kchaou et al. examined the cytotoxic property of Tunisian date fruits, using methanol/water (4:1, $\mathrm{v} / \mathrm{v}$ ), and the result showed that the human cells growth has been significantly decrease after treatment with the date extract (Kchaou et al., 2016). In another study the antibacterial properties and antioxidant activity of Saudi date fruits variety Ajwa, Safawi, and Mabroom, as well as Iranian date fruits variety Mariami was investigated. The date fruits were treated with polar extraction solvents (methanol or acetone) at $4^{\circ} \mathrm{C}$, while the extracted materials were stored at $-20^{\circ} \mathrm{C}$. The storage stability of total anthocyanin content (TAC) was also studied and shows that date variety Mariami had the highest TAC content while Mabroom had the lowest TAC. The total amount of extracted phenolic compounds from dates using methanol as solvent found to be a better solvent compared to acetone. It was reported that different cultivars exhibited different antibacterial properties. The methanolic extract of Ajwa date variety was reported to exhibited antibacterial activity among all studied bacteria: Escherichia coli, Bacillus cereus, Staphylococcus aureus, and Serratia marcescens (Samad et al., 2016). A recent study by Taleb et al. investigated the pharmacological effect of date syrup, which made from the edible part of date fruit, and has been found to be useful in the treatment of several diseases with etiologies involving inflammation and angiogenesis. The authors reported that the polyphenolic compounds occur in date syrup reduce angiogenic responses, e.g., tube formation, cell migration, and matrix metalloproteinase activity in an inflammatory model by exhibiting anti-inflammatory activity mediated by the prostaglandin enzyme cyclooxygenase-2 (COX-2) and vascular endothelial growth factor (VEGF) in endothelial cells. Inflammation was found to be reduced by the administration of the date fruit syrup polyphenolic compounds at 60 and $600 \mu \mathrm{g} / \mathrm{mL}$, as well as suppressed many stages of angiogenesis, including endothelial matrix metalloproteinase activity, invasion, tube formation and cell migration. Interestingly, date syrup shows no cytotoxicity effect. Moreover, the polyphenolic compounds of date syrup were found to significantly reduce 
the expression of COX-2 and VEGF induced by tumor necrosis factor-alpha at both protein level and gene expression in comparison to untreated cells (Taleb et al., 2016). Most recently a study by Khan et al. reported the effects of date, Ajwa variety, on cancer therapy; therefore date fruits might be used as useful as an adjunct therapy with conventional chemotherapeutics to achieve a synergistic effect against breast cancer (Khan et al., 2016).

\section{PERSPECTIVES}

In-vitro and in-vivo studies of several pure aqueous and mixed aqueous/organic solvent extracts of the date palm fruits were found to possess many health promoting effects; including oxidative stress activity, free radical scavenging capacity, coronary heart disease prevention, hepatoprotective, anti-inflammatory, and anticancer activities. However, the nonmixed organic solvent extracts of date fruits are currently not sufficiently covered in the literature. Organic solvents extracts of date fruits will minimize the carbohydrate, which is highly water soluble, concentration in the extracted materials. After multi-gram scale organic solvents extract materials, a systematic isolation and identification procedures need to be followed up to

\section{REFERENCES}

Al-Farsi, M., Alasalvar, C., Morris, A., Baron, M., and Shahidi, F. (2005a). Comparison of antioxidant activity, anthocyanins, carotenoids, and phenolics of three native fresh and sun-dried date (Phoenix dactylifera L.) varieties grown in Oman. J. Agric. Food Chem. 53, 7592-7599. doi: 10.1021/jf05 $0579 \mathrm{q}$

Al-Farsi, M., Alasalvar, C., Morris, A., Baron, M., and Shahidi, F. (2005b). Compositional and sensory characteristics of three native sun-dried date (Phoenix dactylifera L.) varieties grown in Oman. J. Agric. Food Chem. 53, 7586-7591. doi: $10.1021 /$ jf $050578 y$

Al-Farsi, M., Morris, A. and Baron, M. (2007). Functional properties of Omani dates (Phoenix dactylifera L.). Acta Hortic. 736, 479-487. doi: 10.17660/ActaHortic.2007.736.46

Al-Harrasi, A., Rehman, N. U., Hussain, J., Khan, A. L., Al-Rawahi, A., Gilani, S. A., et al. (2014). Nutritional assessment and antioxidant analysis of 22 date palm (Phoenix dactylifera) varieties growing in Sultanate of Oman. Asian Pac. J. Trop. Med. 7, S591-S598. doi: 10.1016/s1995-7645(14)60294-7

Allaith, A. A. (2008). Antioxidant activity of Bahraini date palm (Phoenix dactylifera L.) fruit of various cultivars. Int. J. Food Sci. Technol. 43, 1033-1040. doi: 10.1111/j.1365-2621.2007.01558.x

Al-Laith, A. A. (2009). Degradation kinetics of the antioxidant activity in date palm (Phoenix dactylifera L.) fruit as affected by maturity stages. Arab GulfJ. Sci. Res., $27,16-25$.

Al-Mssallem, I. S., Hu, S., Zhang, X., Lin, Q., Liu, W., Tan, J., et al. (2013). Genome sequence of the date palm Phoenix dactylifera L. Nat. Commun. 4:2274. doi: $10.1038 /$ ncomms 3274

Al-Najada, A. R., and Mohamed, S. A. (2014). Changes of antioxidant capacity and oxidoreductases of Saudi date cultivars (Phoenix dactylifera L.) during storage. Sci. Hortic. 170, 275-280. doi: 10.1016/j.scienta.2014.03.028

Al-Qarawi, A. A., Mousa, H. M., Ali, B. H., Abdel-Rahman, H., and El-Mougy, S. A. (2004). Protective effect of extracts from dates (Phoenix dactylifera L.) on carbon tetrachloride-induced hepatotoxicity in rats. Inter. J. Appl. Res. Vet. Med. 2, 176-180.

Al-Sayyed, H. F., Takruri, H. R., and Shomaf, M. S. (2014). The effect of date palm fruit (Phoenix dactylifera L.) on 7, 12-dimethylbenz $(\alpha)$ anthracene (DMBA)-induced mammary cancer in rats. Res. Opin. Anim. Vet. Sci. 4, 11-18. isolate the pure single organic compound, which is responsible for the biological activity. The reproduction of the most active ingredient in a chemistry laboratory, then industrially, will help in finding cheaper way to develop new drugs and saving the nature, especially endangered species, by which we can protect the medicines of the wild pharmacy.

\section{AUTHOR CONTRIBUTIONS}

RA, JHA, JSA and BA extracted data from literature and helped in draw the chemical structures of the compounds. YB wrote and finalized the manuscript.

\section{COPYRIGHT STATEMENT}

The appropriate permission has been obtained from the nature publishing group for the reproducing of Figure 3.

\section{ACKNOWLEDGMENTS}

This work was supported by SQU grant (SR/SCI/CHEM/15/01) and AGYA grant (AGYA_TP_16_27).
Al-Shahib, W., and Marshall, R. J. (2013). The fruit of the date palm: it's possible use as the best food for the future? Int. J. Food Sci. Nutr. 54, 247-259. doi: 10.1080/09637480120091982

Al-Turki, S., Shahba, M. A., and Stushnoff, C. J. (2010). Diversity of antioxidant properties and phenolic content of date palm (Phoenix dactylifera L.) fruits as affected by cultivar and location. J. Food Agri. Environ. 8, 253-260.

Al-Yahya, M., Raish, M., AlSaid, M. S., Ahmad, A., Mothana, R. A., Al-Sohaibani, M., et al. (2015). "Ajwa” dates (Phoenix dactylifera L.) extract ameliorates isoproterenol-induced cardiomyopathy through downregulation of oxidative, inflammatory and apoptotic molecules in rodent model. Phytomedicine 23, 1240-1248. doi: 10.1016/j.phymed.2015.10.019

Amira, E. A., Behija, S. E., Beligh, M., Lamia, L., Manel, I., Mohamed, H., et al. (2012). Effects of the ripening stage on phenolic profile, phytochemical composition and antioxidant activity of date palm fruit. J. Agric. Food Chem. 60, 10896-10902. doi: 10.1021/jf302602v

Amorós, A., Pretel, M., Almansa, M., Botella, M., Zapata, P., and Serrano, M. (2009). Antioxidant and nutritional properties of date fruit from Elche grove as affected by maturation and phenotypic variability of date palm. Food Sci. Technol. Int. 15, 65-72. doi: 10.1177/1082013208102758

Ashraf, Z., and Hamidi-Esfahani, Z. (2011). Date and date processing: a review. Food Rev. Int. 27, 101-133. doi: 10.1080/87559129.2010.535231

Awad, M. A., Al-Qurashi, A. D., and Mohamed, S. A. (2011). Antioxidant capacity, antioxidant compounds and antioxidant enzyme activities in five date cultivars during development and ripening. Sci. Hortic. 129, 688-693. doi: 10.1016/j.scienta.2011.05.019

Barghini, P., Di Gioia, D., Fava, F., and Ruzzi, M. (2007). Vanillin production using metabolically engineered Escherichia coli under non-growing conditions. Microb. Cell Fact. 6, 1475-2859. doi: 10.1186/1475-2859-6-13

Basu, S., De, D., Khanna, H. D., and Kumar, A. (2014). Lipid peroxidation, DNA damage and total antioxidant status in neonatal hyperbilirubinemia. $J$. Perinatol. 34, 519-523. doi: 10.1038/jp.2014.45

Belmir, S., Boucherit, K., Boucherit-Otmani, Z., and Belhachemi, M.-H. (2016). Effect of aqueous extract of date palm fruit (Phoenix dactylifera L.) on therapeutic index of amphotericin B. Phytothérapie 14, 97-101. doi: 10.1007/s10298-015-0961-z

Benmeddour, Z., Mehinagic, E., Le Meurlay, D., and Louaileche, H. (2013). Phenolic composition and antioxidant capacities of ten Algerian date (Phoenix 
dactylifera L.) cultivars: a comparative study. J. Funct. Food 5, 346-354. doi: 10.1016/j.jff.2012.11.005

Biglari, F., Al Karkhi, A. F., and Easa, M. (2007). Antioxiddant activity and Phenolic content of varios date palm (Phoenix dactylifera) fruits from Iran. Food Chem. 107, 1636-1641. doi: 10.1016/j.foodchem.2007.10.033

Borochov-Neori, H., Judeinstein, S., Greenberg, A., Volkova, N., Rosenblat, M., and Aviram, M. (2015). Antioxidant and antiatherogenic properties of phenolic acid and flavonol fractions of fruits of "Amari" and "Hallawi" date (Phoenix dactylifera L.) varieties. J. Agric. Food Chem. 63, 3189-3195. doi: $10.1021 /$ jf506094r

Boudries, H., Kefalas, P., and Hornero-Méndez, D. (2007). Carotenoid composition of Algerian date varieties (Phoenix dactylifera) at different edible maturation stages. Food Chem. 101, 1372-1377. doi: $10.1016 /$ j.foodchem.2006.03.043

Chaira, N., Smaali, M. I., Martinez-Tomé, M., Mrabet, A., Murcia, M. A., and Ferchichi, A. (2009). Simple phenolic composition, flavonoid contents and antioxidant capacities in water-methanol extracts of Tunisian common date cultivars (Phoenix dactylifera L.). Int. J. Food Sci. Nutr. 60, 316-329. doi: 10.1080/09637480903124333

Chao, C. C. T., and Krueger, R. R. (2007). The date palm (Phoenix dactylifera L.): overview of biology, uses, and cultivation. Hortscience 42, 1077-1082.

Dance, A. (2016). Live fast, die young. Nature 535, 453-455. doi: 10.1038/535453a

Dias, D. A., Urban, S., and Roessner, U. (2012). A historical overview of natural products in drug discovery. Metabolites 2, 303-336. doi: $10.3390 /$ metabo2020303

Eid, N., Enani, S., Walton, G., Corona, G., Costabile, A., Gibson, G., et al. (2014). The impact of date palm fruits and their component polyphenols, on gut microbial ecology, bacterial metabolites and colon cancer cell proliferation. $J$. Nutr. Sci. 3:e46. doi: 10.1017/jns.2014.16

El Modafar, C., and El Boustani, E. (2001). Cell wall-bound phenolic acid and lignin contentes in date palm as related to its resistance to Fusarium oxysporum. Biol. Plantarum. 44, 125-130. doi: 10.1023/A:1017942927058

El Sohaimy, S., Abdelwahab, A., Brennan, C., and Aboul-enein, A. (2015). Phenolic content, antioxidant and antimicrobial activities of Egyptian date palm (Phoenix dactylifera L.) fruits. Aust. J. Basic Appl. Sci. 9, 141-147.

Eoin, L. N. (2016). Systematics: blind dating. Nat. Plants 2:16069. doi: 10.1038/nplants.2016.69

Frost, B., Hemberg, M., Lewis, J., and Feany, M. B. (2014). Tau promotes neurodegeneration through global chromatin relaxation. Nat. Neurosci. 17, 357-366. doi: 10.1038/nn.3639

Garba, M. D., and Galadima, A. (2012). Anti-diarrhoea and phytochemical evaluation of Phoniex dactylifera L. extracts. Appl. Chem. 49, 9808-9812.

Gorrini, C., Harris, I. S., and Mak, T. W. (2013). Modulation of oxidative stress as an anticancer strategy. Nat. Rev. Drug Discov. 12, 931-947. doi: $10.1038 / \mathrm{nrd} 4002$

Guo, C., Yang, J., Wei, J., Li, Y., Xu, J., and Jiang, Y. (2003). Antioxidant activities of peel, pulp and seed fractions of common fruits as determined by FRAP assay. Nutr. Res. 23, 1719-1726. doi: 10.1016/j.nutres.2003.08.005

Hamad, I., AbdElgawad, H., Al Jaouni, S., Zinta, G., Asard, H., Hassan, S., et al. (2015). Metabolic analysis of various date palm fruit (Phoenix dactylifera L.) cultivars from Saudi Arabia to assess their nutritional quality. Molecules 20, 13620-13641. doi: 10.3390/molecules200813620

Hammouda, H., CheİĄrif, J. K., Trabelsi-Ayadi, M., Baron, A., and Guyot, S. (2013). Detailed polyphenol and tannin composition and its variability in Tunisian dates (Phoenix dactylifera L.) at different maturity stages. J. Agric. Food Chem. 61, 3252-3263. doi: 10.1021/jf304614j

Harasym, J., and Oledzki, R. (2014). Effect of fruit and vegetable antioxidants on total antioxidant capacity of blood plasma. Nutrition 30, 511-517. doi: 10.1016/j.nut.2013.08.019

Hazzouri, K. M., Flowers, J. M., Visser, H. J., Khierallah, H. S., Rosas, U., Pham, G. M., et al. (2015). Whole genome re-sequencing of date palms yields insights into diversification of a fruit tree crop. Nat. Commun. 6:8824. doi: $10.1038 /$ ncomms 9824

Hong, Y. J., Tomas-Barberan, F. A., Kader, A. A., and Mitchell, A. E. (2006). The flavonoid glycosides and procyanidin composition of deglet noor dates (Phoenix dactylifera). J. Agric. Food Chem. 54, 2405-2411. doi: $10.1021 /$ jf0581776
Julia, V., Macia, L., and Dombrowicz, D. (2015). The impact of diet on asthma and allergic diseases. Nat. Rev. Immunol. 15, 308-322. doi: 10.1038/nri3830

Karasawa, K., Uzuhashi, Y., Hirota, M., and Otani, H. (2011). A matured fruit extract of date palm tree (Phoenix dactylifera L.) stimulates the cellular immune system in mice. J. Agric. Food Chem. 59, 11287-11293. doi: 10.1021/jf2029225

Kaster, M. P., Machado, N. J., Silva, H. B., Nunes, A., Ardais, A. P., Santana, M., et al. (2015). Caffeine acts through neuronal adenosine A2A receptors to prevent mood and memory dysfunction triggered by chronic stress. Proc. Natl. Acad. Sci. U.S.A. 112, 7833-7838. doi: 10.1073/pnas.1423088112

Kchaou, W., Abbès, F., Mansour, R. B., Blecker, C., Attia, H., and Besbes, S. (2016). Phenolic profile, antibacterial and cytotoxic properties of second grade date extract from Tunisian cultivars (Phoenix dactylifera L.). Food Chem. 194, 1048-1055. doi: 10.1016/j.foodchem.2015.08.120

Khan, F., Ahmed, F., Pushparaj, P. N., Abuzenadah, A., Kumosani, T., Barbour, E., et al. (2016). Ajwa date (Phoenix dactylifera L.) extract inhibits human breast adenocarcinoma (MCF7) cells in-vitro by inducing apoptosis and cell cycle arrest. PLoS ONE 11:e0158963. doi: 10.1371/journal.pone.0158963

Kikuchi, N., and Miki, T. (1978). The separation of date (Phoenix dactylifera) sterols by liquid chromatography. Microchim. Acta 69, 89-96. doi: $10.1007 / \mathrm{BF} 01196983$

Kim, G. H., Kim, J. E., Rhie, S. J., and Yoon, S. (2015). The role of oxidative stress in neurodegenerative diseases. Exp. Neurobiol. 24, 325-340. doi: $10.5607 /$ en.2015.24.4.325

Kotepui, M. (2016). Diet and risk of breast cancer. Contemp. Oncol. (Pozn). 20, 13-19. doi: 10.5114/wo.2014.40560

Lemine, M., Mint, F., Mohamed Ahmed, M. V. O., Ben Mohamed Maoulainine, L., Bouna, Z. E. A. O., et al. (2014). Antioxidant activity of various Mauritanian date palm (Phoenix dactylifera L.) fruits at two edible ripening stages. Food Sci. Nutr. 2, 700-705. doi: 10.1002/fsn3.167

Mansouri, A., Embarek, G., Kokkalou, E., and Kefalas, P. (2005). Phenolic profile and antioxidant activity of the Algerian ripe date palm fruit (Phoenix dactylifera). Food Chem. 89, 411-420. doi: 10.1016/j.foodchem.2004.02.051

Martín-Sánchez, A. M., Cherif, S., Ben-Abda, J., Barber-Vallés, X., PérezÁlvarez, J. Á., and Sayas-Barberá, E. (2014). Phytochemicals in date co-products and their antioxidant activity. Food Chem. 158, 513-520. doi: 10.1016/j.foodchem.2014.02.172

Mayne, S. T., Playdon, M. C., and Rock, C. L. (2016). Diet, nutrition, and cancer: past, present and future. Nat. Rev. Clin. Oncol. 13, 504-515. doi: 10.1038/nrclinonc.2016.24

Michael, H. N., Salib, J. Y., and Eskander, E. F. (2013). Bioactivity of diosmetin glycosides isolated from the epicarp of date fruits, Phoenix dactylifera, on the biochemical profile of alloxan diabetic male rats. Phytother. Res. 27, 699-704. doi: $10.1002 /$ ptr.4777

Mohamed, R., Fageer, A. S., Eltayeb, M. M., and Mohamed Ahmed, I. A. (2014). Chemical composition, antioxidant capacity, and mineral extractability of Sudanese date palm (Phoenix dactylifera L.) fruits. Food Sci. Nutr. 2, 478-489. doi: $10.1002 / \mathrm{fsn} 3.123$

Moss, J. W. E., and Ramji, D. P. (2016). Nutraceutical therapies for atherosclerosis. Nat. Rev. Cardiol. 13, 513-532. doi: 10.1038/nrcardio.2016.103

Mrabet, A., Jiménez-Araujo, A., Fernández-Bola-os, J., Rubio-Senent, F., Lama-Mu-oz, A., Sindic, M., et al. (2016). Antioxidant phenolic extracts obtained from secondary Tunisian date varieties (Phoenix dactylifera L.) by hydrothermal treatments. Food Chem. 196, 917-924. doi: 10.1016/j.foodchem.2015.10.026

Nathan, C., and Cunningham-Bussel, A. (2013). Beyond oxidative stress: an immunologist's guide to reactive oxygen species. Nat. Rev. Immunol. 13, 349-361. doi: 10.1038/nri3423

Newman, D. J., and Cragg, G. M. (2016). Natural products as sources of new drugs from 1981 to 2014. J. Nat. Prod. 79, 629-661. doi: 10.1021/acs.jnatprod.5b01055

Pujari, R. R., Vyawahare, N. S., and Kagathara, V. G. (2011). Evaluation of antioxidant and neuroprotective effect of date palm (Phoenix dactylifera L.) against bilateral common carotid artery occlusion in rats. Indian J. Exp. Biol. $49,627-633$.

Rahmani, A. H., Aly, S. M., Ali, H., Babiker, A. Y., Srikar, S., and Khan, A. A. (2014). Therapeutic effects of date fruits (Phoenix dactylifera) in the prevention of diseases via modulation of anti-inflammatory, anti-oxidant and anti-tumour activity. Int. J. Clin. Exp. Med. 7, 483-491. 
Rautiainen, S., Manson, J. E., Lichtenstein, A. H., and Sesso, H. D. (2016). Dietary supplements and disease prevention - a global overview. Nat. Rev. Endocrinol. 12, 407-420. doi: 10.1038/nrendo.2016.54

Saafi, E. B., Louedi, M., Elfeki, A., Zakhama, A., Najjar, M. F., Hammami, M., et al. (2011). Protective effect of date palm fruit extract (Phoenix dactylifera L.) on dimethoate induced-oxidative stress in rat liver. Exp. Toxicol. Pathol. 63, 433-441. doi: 10.1016/j.etp.2010.03.002

Sajish, M., and Schimme, P. (2015). A human tRNA synthetase is a potent PARP1-activating effector target for resveratrol. Nature 519, 370-373. doi: $10.1038 /$ nature 14028

Saleh, E. A., Tawfik, M. S., and Abu-Tarboush, H. M. (2011). Phenolic contents and antioxidant activity of various date palm (Phoenix dactylifera L.) fruits from Saudi Arabia. Food Nutr. Sci. 2, 1134-1141. doi: 10.4236/fns.2011.210152

Samad, M. A., Hashim, S. H., Simarani, K., and Yaacob, J. S. (2016). Antibacterial properties and effects of fruit chilling and extract storage on antioxidant activity, total phenolic and anthocyanin content of four date palm (Phoenix dactylifera) cultivars. Molecules 21:419. doi: 10.3390/molecules21040419

Siddiq, M., Aleid, S. M., and Kader, A. A. (2013). Dates Postharvest Science, Processing Technology and Health Benefits, 1st Edn. New Delhi: WileyBlackwell.

Silva, C. G., Métin, C., Fazeli, W., Machado, N. J., Darmopil, S., Launay, P. S., et al. (2013). Adenosine receptor antagonists including caffeine alter fetal brain development in mice. Sci. Transl. Med. 5:197ra104. doi: 10.1126/scitranslmed.3006258

Singh, V., Guizani, N., Essa, M., Hakkim, F., and Rahman, M. (2012). Comparative analysis of total phenolics, flavonoid content and antioxidant profile of different date varieties (Phoenix dactylifera L.) from Sultanate of Oman. Int. Food Res. J. $19,1063-1070$.

Souli, A., Sebai, H., Rtibi, K., Chehimi, L., Sakly, M., Amri, M., et al. (2014). Effects of dates pulp extract and palm sap (Phoenix dactylifera L.) on gastrointestinal transit activity in healthy rats. J. Med. Food 17, 782-786. doi: 10.1089/jmf.2013.0112

Taleb, H., Morris, R. K., Withycombe, C. E., Maddocks, S. E., and Kanekanian, A. D. (2016). Date syrup-derived polyphenols attenuate angiogenic responses and exhibits anti-inflammatory activity mediated by vascular endothelial growth factor and cyclooxygenase-2 expression in endothelial cells. Nutr. Res. 36, 636-647. doi: 10.1016/j.nutres.2016.02.010

Thatoi, H., and Patra, J. K. (2011). Biotechnology and Pharmacological evaluation of medicinal plants: an overview. J. Herbs Spices Med. Plants 17, 214-248. doi: 10.1080/10496475.2011.602471
Thompson, L. U., Boucher, B. A., Liu, Z., Cotterchio, M., and Kreiger, N. (2006). Phytoestrogen content of foods consumed in Canada, including isoflavones, lignans, and coumestan. Nutr. Cancer 54, 184-201. doi: 10.1207/s15327914nc5402 5

Tiwari, B. K., Brunton, N. P., and Brennan, C. S. (2013). Handbook of Plant Food Phytochemicals Source, Stability and Extraction, 1st Edn. Puducherry: Wiley-Blackwell.

Vayalil, P. K. (2012). Date fruits (Phoenix dactylifera Linn): an emerging medicinal food. Crit. Rev. Food Sci. 52, 249-471. doi: 10.1080/10408398.2010.499824

Vinson, J. A., Zubik, L., Bose, P., Samman, N., and Proch, J. (2005). Dried fruits: excellent in-vitro and in-vivo antioxidants. J. Am. Coll. Nutr. 24, 44-50. doi: 10.1080/07315724.2005.10719442

Wang, T. T., Schoene, N. W., Milner, J. A., and Kim, Y. S. (2012) Broccoli-derived phytochemicals indole-3-carbinol and 3,3'-diindolylmethane exerts concentration-dependent pleiotropic effects on prostate cancer cells: comparison with other cancer preventive phytochemicals. Mol. Carcinog. 51, 244-256. doi: 10.1002/mc.20774

Wrolstad, R. (2004). Anthocyanin pigments - bioactivity and coloring properties. J. Food Sci. 69, C419-C425. doi: 10.1111/j.1365-2621.2004.tb10709.x

Zangiabadi, N., Asadi-Shekaari, M., Sheibani, V., Jafari, M., Shabani, M., Asadi, A. R., et al. (2011). Date fruit extract is a neuroprotective agent in diabetic peripheral neuropathy in streptozotocin-induced diabetic rats: a multimodal analysis. Oxid. Med. Cell. Longev. 2011:976948. doi: 10.1155/2011/9 76948

Conflict of Interest Statement: The authors declare that the research was conducted in the absence of any commercial or financial relationships that could be construed as a potential conflict of interest.

The reviewer KK and handling Editor declared their shared affiliation, and the handling Editor states that the process met the standards of a fair and objective review.

Copyright (c) 2017 Al-Alawi, Al-Mashiqri, Al-Nadabi, Al-Shihi and Baqi. This is an open-access article distributed under the terms of the Creative Commons Attribution License (CC BY). The use, distribution or reproduction in other forums is permitted, provided the original author(s) or licensor are credited and that the original publication in this journal is cited, in accordance with accepted academic practice. No use, distribution or reproduction is permitted which does not comply with these terms. 